\title{
THE HORIZONTAL METROPOLIS: A RADICAL PROJECT
}

VIII INTERNATIONAL PHD SEMINAR 'URBANISM \& URBANIZATION' | SYMPOSIUM LATSIS EPFL 2015

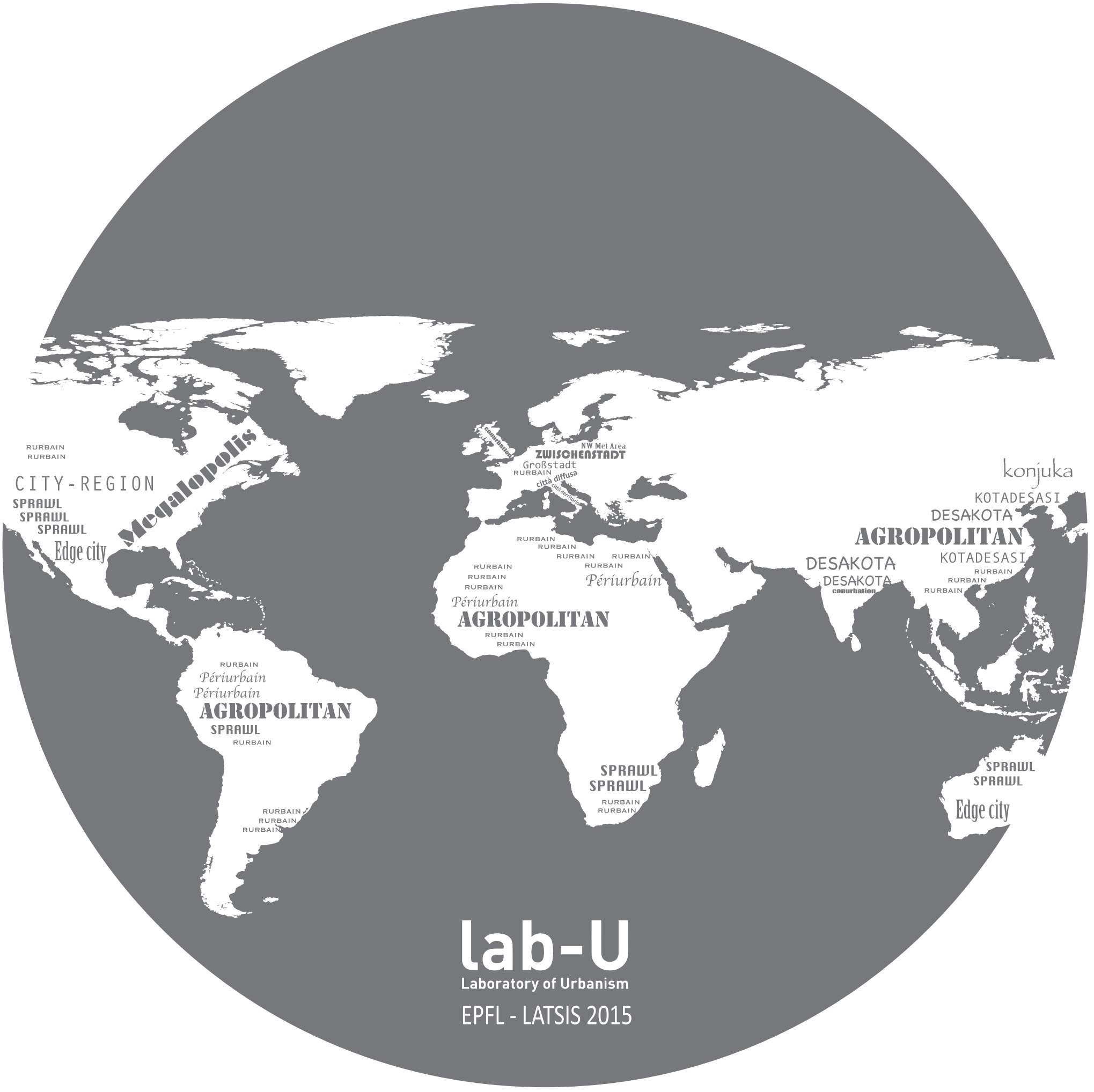

LAUSANNE | 12, 13, 14 OCTOBER 2015

Conference Proceedings 


\section{THE HORIZONTAL METROPOLIS: A RADICAL PROJECT}

VIII INTERNATIONAL PHD SEMINAR ‘URBANISM \& URBANIZATION’ | SYMPOSIUM LATSIS EPFL 2015 


\title{
Abundance of interplays delivered by scattered patterns of occupation. San Joaquin in Cuenca, a case of study in the southern highlands of Ecuador \\ Name of Author: Monica Rivera-Muñoz
}

\author{
Affiliation: Department of Architecture, KU Leuven \\ Supervisor: Prof. Bruno De Meulder \\ Expected thesis defense: February 2018 \\ Email:monicariveraed@,hotmail.com
}

The problematizing of generic dispersion as a general evil of growing cities, has led to a too-easy diagnosis with the same 'illness' to rural territories surrounding and under the influence of middle size cities in the central and southern Ecuadorian Andes. As a consequence of such diagnosis, development plans for these proto-urban territories show a widespread tendency to propose densification as an antidote to battle dispersion. Very commonly, these plans neglect strategies that consider the rationalities behind those rural lands sprinkled with emerging urbanity, or their complementary roles in the broader context of their territory.

During pre-colonial times, the scattered distribution of the groups in the Andean region were based on the desire to use and control diverse ecological units. This allowed them to ensure the alimentary autonomy of the different groups of population in the Cañari territory, in the southern part of today Ecuador. During colonial times, the heterarchical quality of productive complementarity between diverse groups in the territory was transformed and acquired a hierarchical character. In this new schema, Cuenca, the Spanish-founded city established on the lands of Cañari and Inca preexistences, was meant to be at the top, as an instrumental center of territorial and population control. However, even after the city became that fundamental space, its meaningfulness and survival couldn't stand alone. Cuenca was highly dependent of the resources and work in the hinterland, remaining closely related to the population of the constellation of rural settlements that surrounded it. Besides being able to endure the rule of the city, this population learnt to interact with the multi folded conditions of a city that attracted as much as it repelled them, that offered as much as it consumed from them, that opened opportunities as much as it closed spaces for them.

It is clear that scattered patterns of occupation are characteristic of rural agricultural territory in the studied context, and that subdivision of land is more intensive in zones closer to urban centers. However, a careful reading of the territory, in combination with interpretation of the structuring elements of its landscape, might shed light on the interaction between spatial, social and cultural factors that have contributed to render the present conditions of occupation in the southern Ecuadorian highlands.

In Ecuador, the study of urban development of cities has mostly been addressed from a historical and chronological perspective, and it has constrained itself to the analysis of the consolidated zones of urban fabrics. These studies, regarded exclusively as historical narratives, have not been able to effectively contribute to a spatial understanding of the territory. It becomes clear that a new approach that undertakes the spatial analysis of landscape is needed in order to unveil its logics, relations, processes and elements. Such a wider understanding of the context is essential to envision possible futures, underpinned in its own characteristics and potentialities, and as a way to counteract the homogenizing forces of market-driven urban expansion and lack of culturally sensitive approaches from local planning bodies.

Departing from a combined historical and spatial analysis on the processes that developed into the scattered patterns of settlement present in the southern highlands of Ecuador, this paper undertakes the reading and interpreting one of the rural parishes of Cuenca, San Joaquin. The case study constitutes on of the last pieces of flat productive landscape of intensive use on the valley of Cuenca. This is a context where migration has emptied the population of the rural areas population, and most flat and fertile soils have been already consumed by urbanization, resulting in increasing food dependency on trade with other regions and countries.

The closeness of San Joaquin to the city in combination with ethnic-segregationist land grants during early colonial times and influence of roads, have shaped the character of its territory and population: its double nature as agricultural and urbanized land; its patterns of settlement as scattered and linear; their people activities as peasants, artisans, merchants, laborers and most recently as professionals that work in the city; the practices of its population as simultaneously urban and rural.

This study analyses the rationalities behind the landscape of scattered occupation in the southern highlands of Ecuador, through the construction of a spatial narrative of the proposed specific landscape. The interplay between its natural systems -such as abundance of water, rich soils, flat topography and irrigation systems, and the less obvious socio cultural constructions are explored. The changing nature of the landscape and its population is also explored, and esential for a full understanding of the territory.

Scattered patterns of occupation can also be sustainable ways of inhabiting the territory, due to a quality of complementarity, and multitude of interplays delivered in the pattern. Because landscapes incremental capacity of building social and economic networks for their inhabitants, the present study is understood as a tool to envision and explore future possibilities of integration between the pressuring processes of urbanization in San Joaquin and its productive landscape, which can be account as an available resource for their population.

Mapping of the elements of the landscape, comparative analysis and interpretation of historical maps and orthophotography, in combination with scrutiny of historic narratives is the methodology to be undertaken. Multiple sources of information nourish this case study, however, performed fieldwork (direct observations, sketches and interviews) is essential in understanding the subtle and many times, invisible relations existent between places and people. J.B . Jackson's work on vernacular landscape becomes a lens to study the landscape for the proposed case study. Conzen's 
studies on urban morphology and its vocabulary, are visited as a tool to interpret the case study, as well as for their utility to express contents in a less ambiguous manner.

\section{Introduction}

Cuenca is a city in the southern highlands of Ecuador. With 500.000 inhabitants, it is the third largest city in in the country. Its urban area houses two thirds of its population, while the remaining are dispersed in the rural parishes that surround Cuenca. Cuenca is located in the centre of the Paute river watershed [fig.1], enclosed by mountains and crossed by four rivers. As other Andean cities, it was founded during the colonial period. The Spanish city superimposed itself over the ruins of Tomebamba, a ceremonial Inca city which was, in turn, built on Guapondelig, the center of a Cañari cacicazgo ${ }^{1}$.

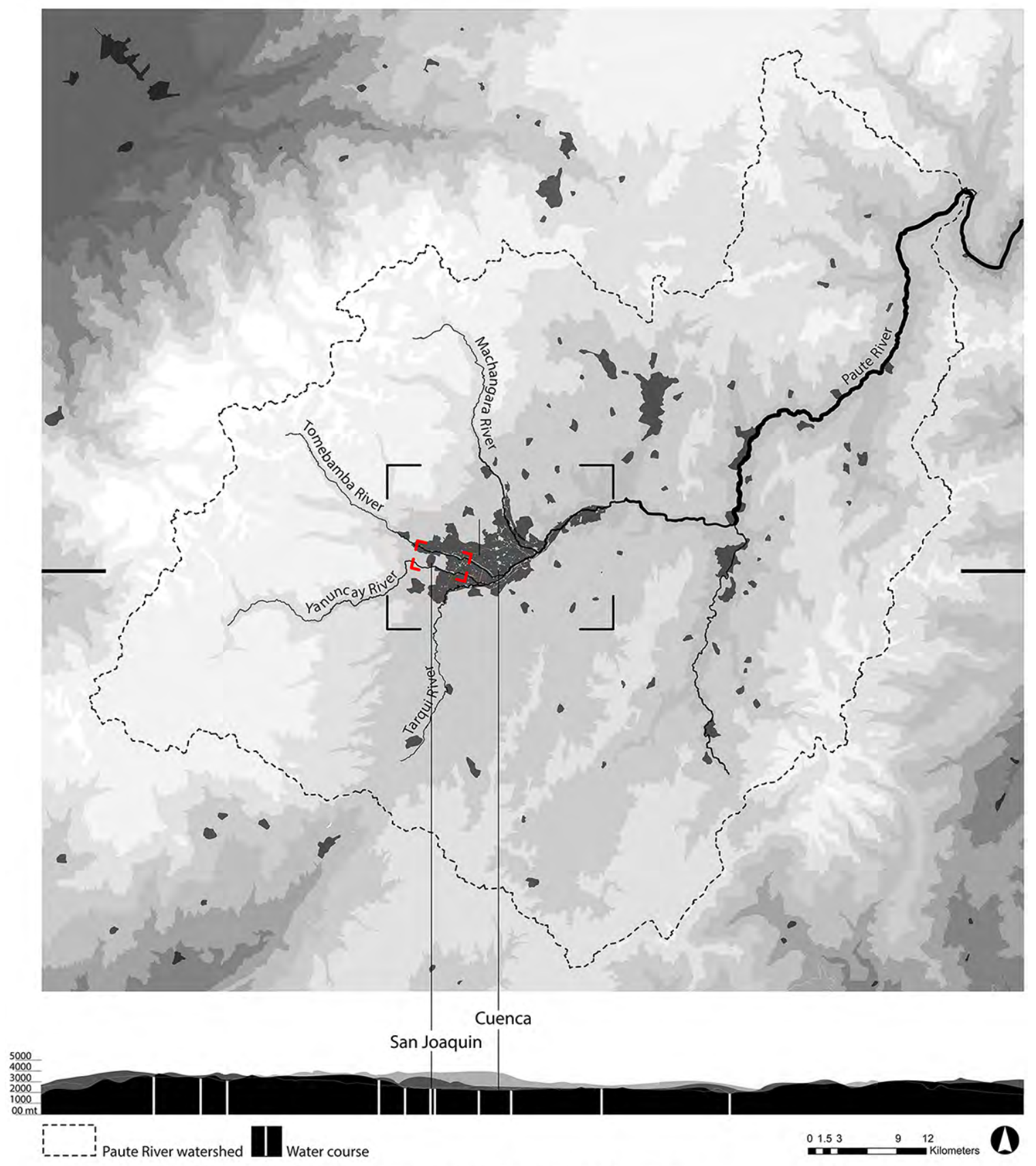

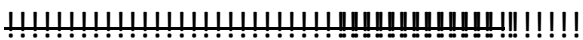

${ }^{1}$ Cacicazgo was a regional unit of socio-political organization in the Andes. It was comprised by several family based units (Ayllus). Ayllus were grouped around a Llajta, which was a symbolic nucleus where the ethnic authority had seat, and worked as a center of cohesion and organization. 
[fig.1] Paute river watershed. Source: elaborated by the author, from GIS information, Senplades (Ecuadorian National Secretary of Planning).

Cuenca is surrounded by a constellation of small and medium-sized rural centralities, whose space of occupation often dates back to pre-colonial times. During the colonial era, existing and newly-created villages were used to concentrate indigenous population. These Indio towns ${ }^{2}$ became fixed and were restrained to the mountainous and other secondary peripheral spaces. Main and secondary towns were articulated into 'parishes'3, with the objective of accomplishing several objectives at stake: gaining control over indigenous labour, freeing land for land concessions to settlers and/or facilitate evangelization of indigenous people. In practice, indigenous population didn't concentrated as it was intended by Spanish authorities. Until no more than forty years ago, an Indio town was -from a conventional definition of what is urban, no more than a small nucleus conformed by a church, an earthen plaza and some houses around it. Even today, while most of the towns have developed, these nuclei are still the symbolic centres for the parish. As most of these settlements, they don't translate into compact urban conformations. The rest of the population lives scattered across the parish's rural territory. Evidently subdivision of land is more intensive in zones closer to these nuclei, although tiny proto-urban concentrations can appear here and there across the whole parish. The success and permanence of a town since the colony era is depending on their closeness to the city, with which they weaved strong ties of dependency and complementarity. As the city increased its influence over the territory, new villages emerged in its proximities. However, their conformation and logics, often repeated those of the Indio towns.

Read through the lens of urban expansion, the disperse occupation patterns in the parishes are conventionally problematized as "urban sprawl'. Consequently, development plans for these proto-urban territories show a widespread tendency to propose generic densification as an antidote to battle dispersion. Frequently, these plans neglect the rationalities behind those rural lands sprinkled with emerging urbanity, their complementary roles in the broader context of their territory, the system values of these constellation of centralities and its contribution to the conformation of the cultural, social, economic and demographic identity of Cuenca.

This paper analyses one of the rural parishes of Cuenca, San Joaquin. The case study is one of the last pieces of intensively used flat productive landscape in the valley of Cuenca. It is mostly surrounded by urbanization, and this condition puts enormous pressure over this territory. Problematized as a pocket that impedes communication between north and south in the expanding western part of the city, the local Planning Department has recently approved a road-based spatial planning for the sector, which would result into a drastic end to the current agriculture-based activities in the area. The importance of qualifying the productive landscapes that surround Cuenca are related to the sustainability of the city. Migration has emptied rural population and most flat and fertile soils are consumed by urbanization, resulting in increasing food dependency of Cuenca on trade with other regions and countries.

\section{The ejido ${ }^{4}$ lands: a multidimensional and long term condition of In-betweenness}

'Matadero River (Tomebamba) is between Cuenca and el Ejido. (...) Seen from the upper terrace of Cuenca, El Ejido looks fascinating, so much for its extension and perpetual greenery, as much as for it resembles a second city, divided in numerous quarters with houses, gardens, orchards and beautiful groves which makes from all a charming combination. (...) Beyond the Ejido are the quintas $^{5}$ and then, the vast plain of Tarqui, which ends in the knot of Portete. This wonderful plain is watered by numerous rivers, which provide great number of irrigation channels for the ejido, quintas and plains' (Manuel Villavicencio (1858) quoted in Leon, 1983, 76) ${ }^{6}$.

Intensive division of land, houses, gardens, orchards, groves, flat topography, and a system of irrigation channels all in relation to the rivers that crosses the valley seem to be main elements that defined this landscape that is so vividly described by Villavicencio in the middle of nineteenth century. The fragment by Villavicencio, written around the time San Joaquin appears as a rural centrality, well could be describing its condition: privileged by its flat topography and abundance of water, and located only 5 kilometers away from the colonial core.

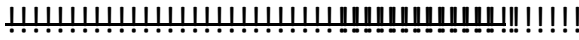

2 The Spanish called them "pueblos de Indios". Since the 1990, there have been a series of indigenous political movements in Ecuador which have reivindicated the word "indio." This has gained popularity among indigenous groups and it is now used as a manner of expressing their pride for their community. For that reason, I have chosen to use the term indio instead of a translation of it.

${ }^{3}$ The "parish" was originally a territorial unit of ecclesiastical and royal administration, which after independence continued to be used as a territorial unit of state administration.

${ }^{4}$ Land reserved for common and shared use. Ejido lands were property of the city, and managed by the city Council. Usually they were rented on the basis of long-term contracts that could be renewed from one to the following generation in the same

${ }^{5}$ Land property of medium scale, used for cultivation and bred of animals for the domestic consume.

${ }^{6}$ Original text in Spanish. Translation by the author. 
The proto urban quality of the ejidos morphology seems to have been generated at a very early stage during colony, by the attraction that the city effectively had ${ }^{7}$ over the newcomers as much as over the indigenous people, and by a land market, started by the very City Council. Insufficient funds to cover all the expenses of the new city, had driven the Council to sell the plots inside the urban grid, and to rent and sell land in the ejidos as a way to fund its treasury (Chacón Zhapán , 1990, 379).

"There must be, more than four thousand souls of both sexes, most of them mestizos. However, despite they are so close to the city, they are the ones most lacking, in the whole jurisdiction, of the Christian doctrine" (de Merisalde y Santisteban [1765], 1894) ${ }^{8}$

The dynamic space that emerged on the other side of the Tomebamba, was populated by a very diverse stratum of people, that can be conceptualized as peripheral in several senses. The above fragment by Merisalde alludes simultaneously to a condition of immediacy and remoteness of what was considered to be 'good': city and religion. A certain quality of openness seems to have been inherent to these lands. Peripheries were not under strict control of the city, because they were outside of it, but also sufficiently far from the Indio towns to be part of them. This indeterminate status, this 'gap', may lead us to think of these spaces as a sort of a no-man's land of freedom and opportunity.

The higher tributes that the members of indigenous communities had to pay in relation to the ones who had decided to abandon them, had triggered intensive migratory movements of indigenous population across the whole territory, fragmenting their communities during early colony (Simard, 1997; Chacón Zhapán, 1990; Achig, 2012). Lands in the peripheries meant a huge asset for indio fugitives ${ }^{9}$ escaping from their burdens, but also for poor whites with no chances for buying land in the city. It could be said that this was the place of the outcasts. With relatively little or no restrictions, the peripheries became very dynamic places of rich cultural blending, where diverse population interacted and mixed. Over time, solidarities reappeared, population identity was forged as peasant and the communities were able to reconstitute[fig.3].

Located in farer ejidos of Baños, between the Yanuncay and Tomebamba rivers, San Joaquin area come to be known as the land of indios libres ${ }^{10}$. It was close to medium size haciendas -as sources of seasonal work; to communal lands of indigenous occupation -for having seasonal workers; and to the city -the place where opportunities could be exploited to obtain income ${ }^{11}$ [fig.2].

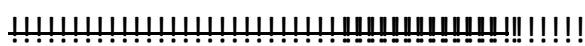

${ }_{7}$ Cuenca had been founded in 1557 with only 18 neighbors (heads of family). By 1570 they are calculated to have been 60; by 1574, 80; by 1582,150 . See (Poloni-Simard, 2006,73)

${ }^{8}$ Original text in Spanish. Translation by the author.

9 They were called forasteros, which means foreign, stranger. Belonging to a community was essential to the identity of indigenous peoples, the decision of abandon their communities implied the uprooting of their identity, to stop being.

${ }^{10}$ Indios libres translation to English is "free natives"

${ }^{11}$ Tribute, that during precolonial times was in kind and related to the communal work capacity of production, was monetized during colony era. Tribute was an obligation that the community had to face together as community, then that monetary compensation was not an individual objective but a communal one. Spanish colony didn't enslave indigenous population, however, the obligation of a monetary tribute served well the purpose of exploiting indigenous labor force. 


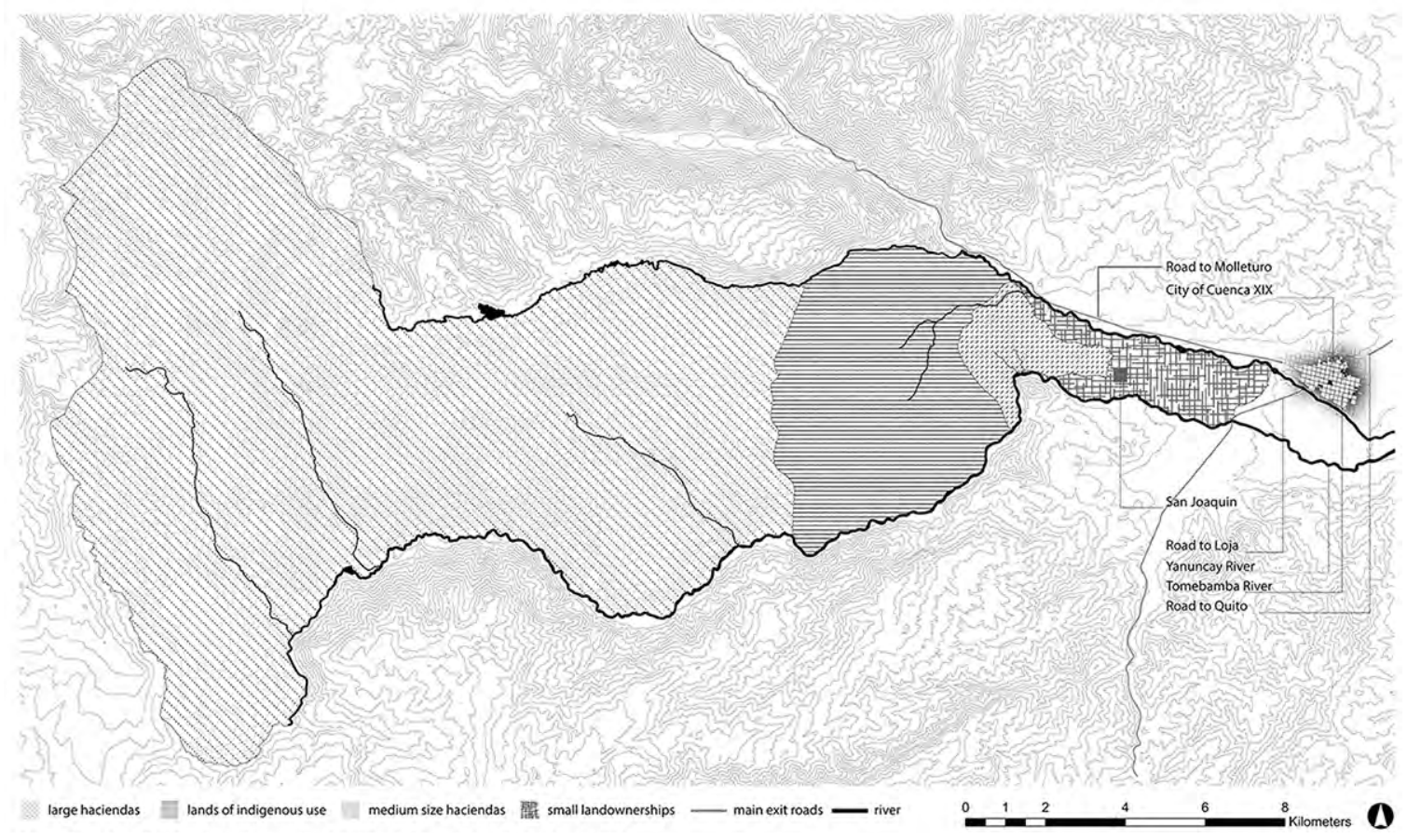

[fig.2] The condition of land tenure around mid XIX century in San Joaquin parish. Source: elaborated by the author, from GIS information, Senplades and Juan Loyola, 2012.

The heyday of exportations of toquilla hat during XIX century, a highly labor demanding product, kept busy the rural as much as to the urban population of the valley of Cuenca, and accentuated its attractiveness. Almost every rural center in the proximity of Cuenca, among them San Joaquin, became a center of hat weaving, an activity alternated with domestic agriculture. The peripheries became active spaces, with a population that regularly came to the city, either for buying raw material, or for selling finished hats (Chacon et al, 1982; Palomeque, 1990). It was out of this 'in-between' condition that Cuenca and its parishes built their identity, from a strong interplay and coexistence of its urban and rural practices, its creole, indigenous and peasant population; but also from its attachment to traditions and simultaneous aspirations for modernization.

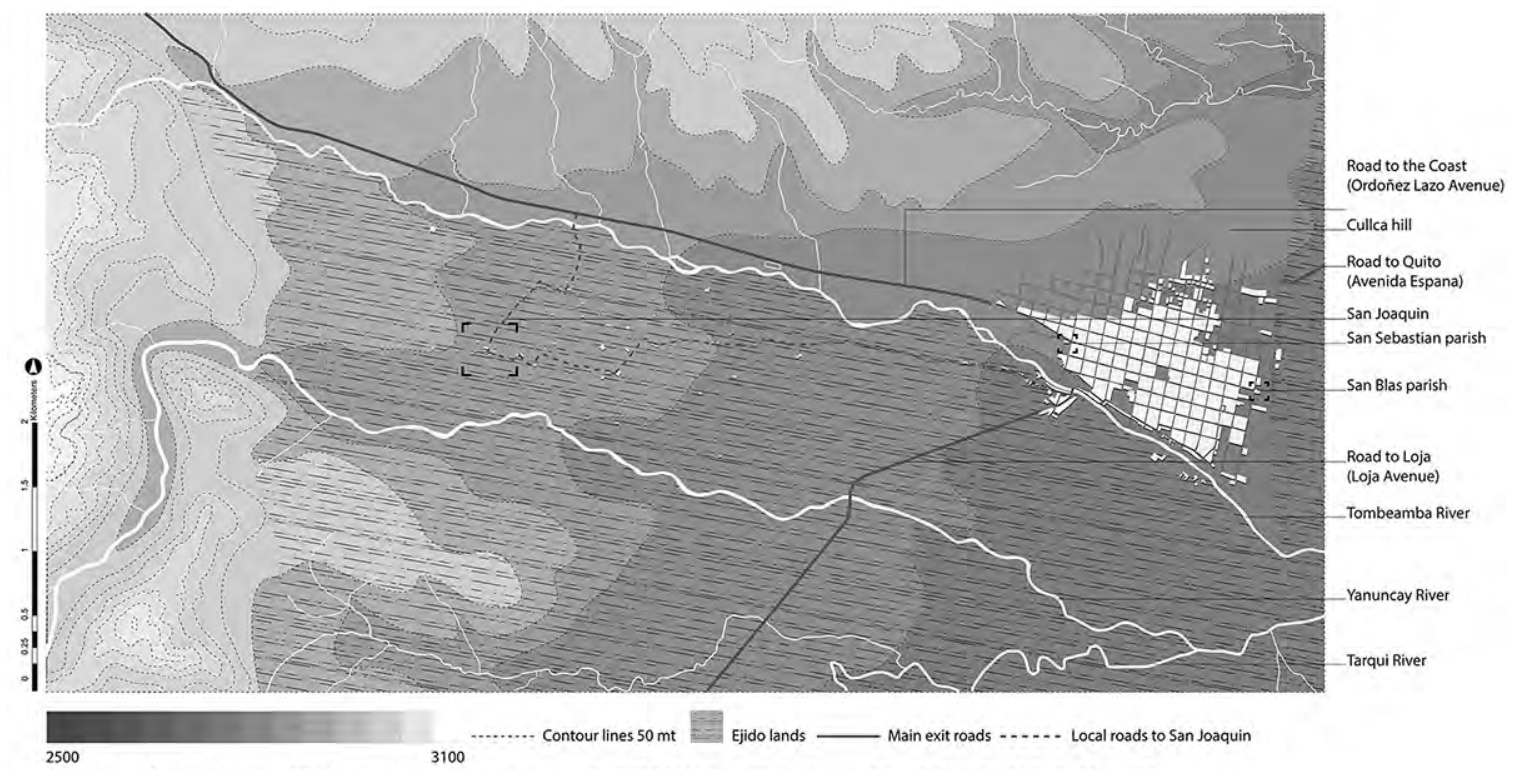

[fig.3] Initial alimentary dependence on indigenous people production was fought through concessions of land in the ejidos, especially those to the east of the road to Loja. Ejido lands close to mountainous space remained as spaces with less restrictions. Source: elaborated by the author, from GIS information, Senplades and lithograph by Salvador Mora, 1878 


\section{Dynamic interplays in the territory}

San Joaquin is not in the mountains, and it was not an Indio town. Strictly speaking, San Joaquin is an exception to the rural parishes that surround Cuenca. At the same time, San Joaquin exemplifies several common issues to their dispersed ways of occupying the territory: the mostly small and medium size of landholdings, the diversified nature of the economic activities of their population, the in-between condition of a population that merges challenges and advantages of two worlds, the rural and the urban. It is also common to these territories to have an elevated migration rate and the impact of remittances in the transformation of their landscape is often structural. Nowadays they also face the poor esteem for agricultural activities, and the rapid transformation of these territories under the high urbanizing pressure combined with a weakening peasant culture, especially in the proximities to the city [fig.4].

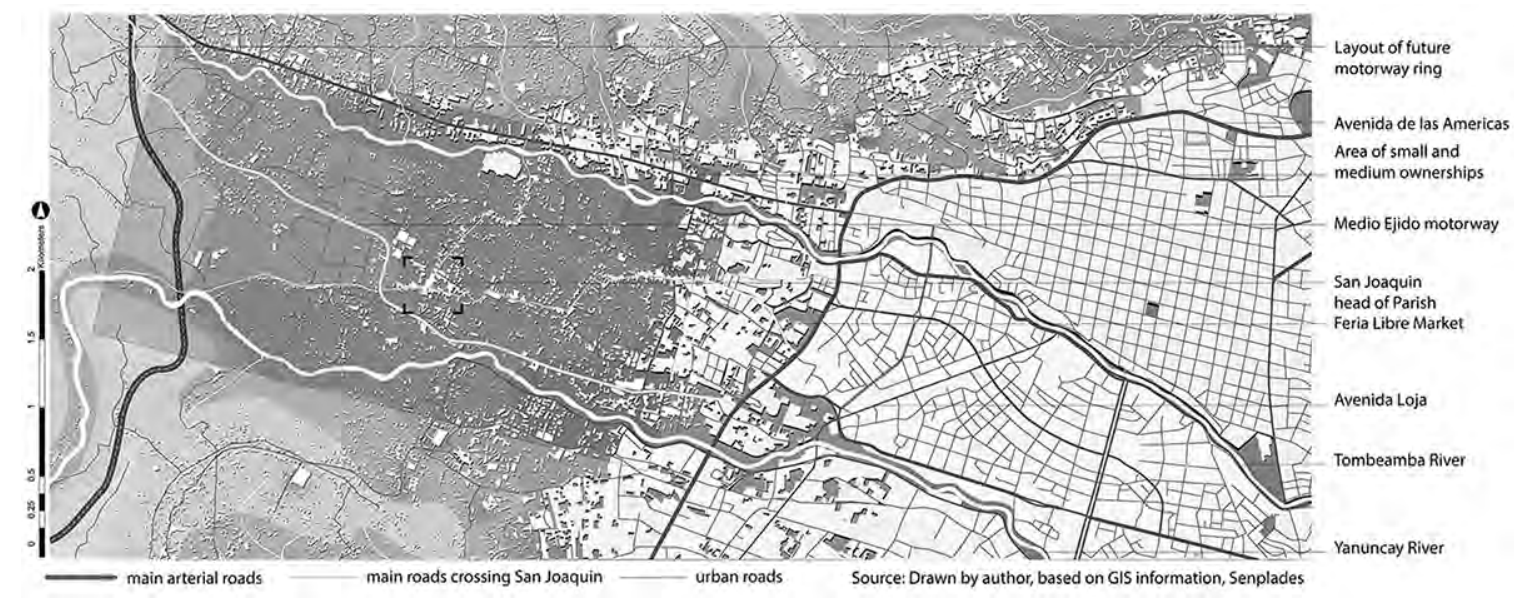

[fig.4] Current condition of San Joaquin in relation to the dense urban tissue. Source: elaborated by the author, from GIS information, Senplades.

San Joaquin is strongly defined by its favorable topography, fertile soils, abundance of fresh water, closeness to the city and very importantly by the resilience of its population. In the course of time, they have been able to adapt and educate themselves, reacting to the changing economic realities of the region. Simultaneously, in a very active manner they have networked their territory with paths, water channels and $\operatorname{cercos}^{12}$ towards the continuation of agriculture, an activity of cultural and economic relevance for them ${ }^{13}$. [fig.5] 

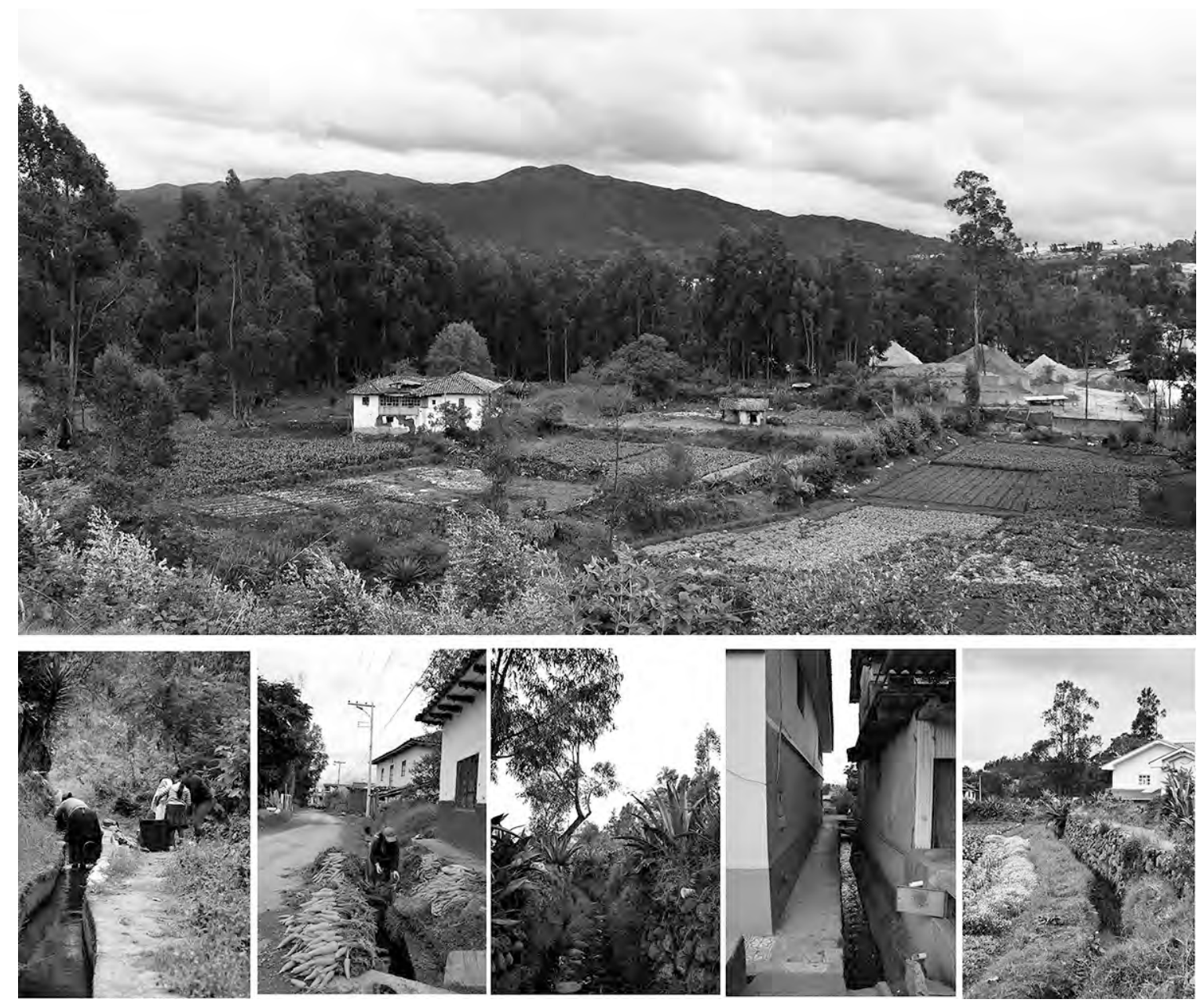

[fig.5] Diffuse and meandering boundaries are a characteristic of San Joaquin landscape. The clearing of land for cultivation results in an endless construction and thickening of cercos. Some have grown so robust that they have turned into elevated pathways. At crossroads they become nodes, spaces with substance, thickness, and height where people can meet. Two simultaneous roles are now performed, the most basic of separating what is yours of what is mine, and another, opposite, yet complementary, of bringing us together again. Source: Author

For a long time, San Joaquin has profited from this advantageous in-betweenness that shaped its territory and population: its double nature as agricultural and urbanized land; its patterns of settlement as scattered and linear; its people's activities as peasants, artisans, merchants, laborers and most recently as professionals that work in the city. The practices of its population are simultaneously urban and rural, dependent and nondependent, fixed and flexible. The cycles of their activities continuously alternate between those activities that rely on land, and those that have to be accomplished far from it.

Official data shows that agriculture is no longer the number one economic contributor for the parish (Municipality of Cuenca, 2011). However, official data might not reflect the real economic impact of agriculture in the households of San Joaquin. Commercialization of agricultural products is mostly performed in the wholesale market, where commerce is performed spontaneously, and the charges of state taxes are rather unusual. Consequently, these transactions are not traced by the S.R.I. (System of Internal Revenue) or officially reported. Additionally, fieldwork made evident that other activities such as commerce and transport services are possible because of agriculture or they are directly related to it.

People's appreciation for agriculture is ambivalent. As inhabitants of the parish, they express their pride for the fertility of the soils, quality of the products, agricultural activities and their peasant culture. However, at a personal level, a sort of shame was outspokenly or timidly expressed by most of interviewed farmers, especially among men. It is as if practicing agriculture was not a question of free election, but what is left to those who have not learned a trade.

Still deeply embedded in the local culture, agriculture is nevertheless a continuous struggle they have been ready to engage (Carrillo \& Carrillo, 2015). On the one hand, the spaces of direct commercialization for the producer have been continuously reduced in the city. On the other hand, the spatial and use regulations imposed by the local government over this territory doesn't answer to the needs or aspirations of its 
inhabitants. Planning is still implemented from the 'city' point of view, then that these territories continue to be seen as places to be controlled through generic urbanization.

\section{Markets and Informality}

Formalization and concretion ${ }^{14}$ of markets started during the city modernization at midcentury. A continuous reduction of the spaces of direct commercialization for producers followed, and also a certain degree of specialization in their activities. Having to choose between remaining producers or fully becoming merchants, the accomplishment of both roles became a continuous struggle, especially for small producers, for whom the higher prices that direct sale consumers can contribute is critical. The temporal character of the farmers commercial activities has never been thoroughly understood in its crucial role within the productive cycle, whose completion ensures its further reproduction. The complementary role and contribution to the city of the multiplicity of small scale producers also remains unqualified. Instead, their small scale commercialization has been demonized because of its 'informality' and generalized as an urban problem, remaining neglected of effective and specific answers to its condition.

"Informality" is indeed just another dimension of the 'in-between' condition that indigenous and peasant population has faced and still faces in performing their activities. During colony, two Indio Parishes, San Blas and San Sebastian had been created soon after its foundation, to perform as eastern and western limits of the city. Their location had a double purpose: to act as control centers for the indigenous population of the territory, and to exclude them from the city by defining the closest points to which they could reside. However, the settlers need of labor work, combined with the monetization of the indigenous tribute during colony era, forced the native population into the market system, by selling their products or labor force in the city. Since then, their presence was both required and contested ${ }^{15}$. 'In-betweenness' is not an exception but the very condition in which indigenous and peasant population have forged their own worlds, and the 'informality' to which we refer today, is only reproducing this long-term condition.

The wholesale market "Feria Libre" [fig.6] was created in the early seventies, and located close to the productive lands in order to support the farmers activities. It was meant to be a market of free and temporal use by the farmer. However, its very success and the growing political power of the diverse merchant organizations that emerged, transformed it into a formalized market of fixed and allocated posts. Over time, the space for direct commercialization by local farmers has been reduced so much that currently it doesn't account for more than the $1.5 \%$ of the total area of commercialization in the market.

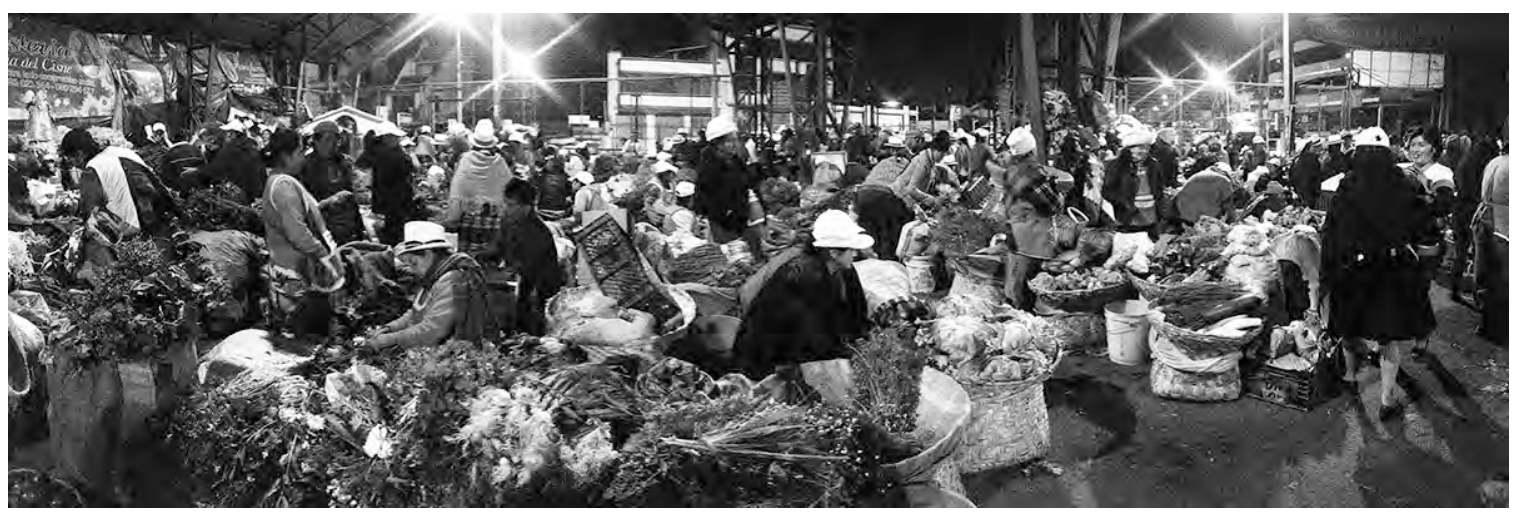

[fig.6] Sales start at 3am in Feria Libre wholesale market. Producers can only sell their products until 9am. Source: Author

\section{Agriculture as family-based [re]production}

Agriculture production in San Joaquin can still be understood as family-based production. The participation of the members of the household and the multiple roles they perform, are crucial in the construction of their local and regional networks of commercialization, and in the retention of their claimed spaces in the city. The case of Doña Julia, a flower seller in the Colonial Center of Cuenca, will help to illustrate several conditions regarding family based production and its transformations in San Joaquin.

Native from another parish, she arrived to San Joaquin almost 50 years ago, brought by an aunt who knew about the labor opportunities that San Joaquin offered in agriculture, even before the intensification of commercial horticulture. After marrying a local farmer, she became part of an extended family, with his

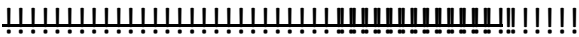

14 "concretion" refers to the building of permanent structures replacing temporal ones. In Alnwick, Northumberland: A Study in Town-Plan Analysis, Cozen describes a slow process of replacement of old structures in the market by new ones. In the present text the term helps to describe the process by which the market not only is formalized, but becomes fixed to a building. See also: Larkman and Jones, Glossary of Urban form, 1991.

${ }^{15}$ See J. C. Chacón Zhapán 1990, pp 379 
parents and one brother. While all performed agricultural shores, her parents in law were the ones in charge of traveling weekly to Duran, a coastal town, to sell the bulk of their flowers production. She and her mother in law were the ones in charge of the commercialization of the remaining production on the local market. The market was then and still is a space dominated by women, both as buyers and sellers. Later, when her parents in law became old, it was she and her husband that traveled, while her mother in law stayed in charge of local commercialization in the colonial center. By then, she started to take also some vegetables together with the flowers, as a complementary product. (Narvaez, 2015)

The degree of involvement of the family members in the shores of labor and commercialization is diverse. Variables such as the structure of the family, levels of formal education, aspirations of its youngest members, in combination with the impact of agricultural activities on the family economy are fundamental in defining the intensity of their participation in the productive cycle. Eventually, the interplay of these variables will define the continuity of the agricultural activity or not in a family group.

The raise of a money driven economy has reduced solidarity-based family economies. The trend has moved towards single family as production unit, and rapidly towards adults being the only ones working the land. Differently than Doña Julia, when her children got married, they conformed nuclear families. Doña Julia, has five daughters, four dedicated to agriculture and commerce, and one who emigrated 14 years ago to United States, after having worked also in agriculture for some time. The simplification of the family structure has reduced their spatial capacity of action, from multiple market niches to the conservation of only one market niche in the city, abandoning the commerce trips to the coast, as their production also decreased. Rosa sells next to her mother in the Flowers Market during weekends and holydays. Fanny, has a stall in the wholesale market of Cuenca "Feria Libre", where she sells not only her production, but also some of Rosa's vegetables.(Guaman,F., 2015) Rosario, the most entrepreneurial, opened a new market niche, selling to one of the biggest supermarkets in the city, with daily deliveries. The land that Rosario already received from her parents as inheritance some years ago, is not enough to sustain her family, so she rents multiple plots in San Joaquin and in neighboring parishes to increase her production and cover her sales. (Guaman,R., 2015)

For others, their land will remain uncultivated as consequence of migration, old age, lack of time or simply lack of interest due to other higher sources of income. A uncultivated plot, however, constitutes an opportunity for those still farming or willing to do so.

\section{Transitional economies}

Some farmers in San Joaquin do not own land. People like Silvia Pindo, native from Quingeo, have come because San Joaquin offered them work, very scarce in her place. Silvia and her husband came eight years ago, initially working as day laborers. Over time, her husband became a construction worker in the city and she started to rent plots and buy the production of other farmers for selling it at the wholesale market. (Pindo, 2015) The fragmented character of land in San Joaquin allows to accommodate this kind of 'transitional' family economies [fig.7] Owning land is improbable for Silvia due to its high cost in the area. Eventually, she will return to Quingeo, where she has bought a plot of land for her house, and where she thinks she would dedicate herself to raise small animals instead of cultivating.

Like Silvia, many others have come and have stayed in San Joaquin, where besides being day laborers, they also offer a whole palette of agriculture-related services such as: plowing and preparation of soil, weeding, harvest and post-harvest services.(Villacis, 2015) Verbal agreement over a determined amount of work and with a fixed payment is a very common way of commitment between the parties, and can be used for diverse scales of work with flexibility. Silvia values very much this advantage of living in San Joaquin. - "They always ask for my help", she says referring to her neighbors, "and they always pay me something, then I can get something extra for my kids". (Pindo, 2015)

According to several women interviewed during field work, (Pindo, 2015; Chabla, 2015; Barros, 2015; Wishco, 2015) agriculture offers flexibility for raising their small children: - "to me is better to rent and work on my own", says Silvia Pindo, - "in this way my kids are not neglected. I wait for them after school and they are with me all the time".(Pindo, 2015) This is an asset that a formal wage work would not offer to her family. For many interviewed women, agriculture, specially cultivation, is an activity they would be willing to abandon after their kids grow up. Other interviewee, Maria, works today as a maid in the city. Having inherited a small plot enough only for her house, she used to work as day laborer for other farmers until her kids finished elementary school. (Barros, 2015) With access to better quality education, because its immediacy to the city, and having never cultivated, it is most probable that her kids will never work the land.

\section{Non-Agricultural income}

Complementary activities increasingly contribute to the domestic economy. More often than not, it is the father rather than the mother who tries to suplement the monetary income for the family through another activity. Skills and education define his employability, however, landownership can determine the outcome: laborer, immigrant or independent worker. A plot of land is very often mortgaged to endorse the purchase of 
a vehicle for taxi or transportation services, an activity very appreciated and with a certain status between men in the parishes.

Even though paying a smuggler does not guarantee entry into the United States, sometimes a plot will be put at risk to get a fast cash loan for paying such a risky business. A chain of threats from kidnapping to extortion, from sexual violence to death, await those who dare to attempt such crossing. Carmita, another seller in the Flowers market native of San Joaquin, lost her husband 10 years ago, when he decided to emigrate. The couple worked together in the production of vegetables and flowers, but his desire to finish the house they were building made him venture into attempting to cross into the United States. Carmita never heard from him again, she presumes he died in the journey.(Narvaez, 2015) The dream of improving their living conditions vanished, her family is broken, and she was left with debts that she had to face alone.

\section{Reinventing traditions: agro-ecological production}

Higher levels of education amongst farmers children can work in both ways, drawing them away from the fields, but also tying them more strongly. Luis Villacis is the son of a well-known farmer and leader in San Joaquin. He is an agricultural engineer with almost 15 years of experience in horticulture with an innovative approach. He combines agro-ecological practices while reducing commercial chains, in order to maximize profits. Rejecting the still prevalent use of chemical fertilizers and pesticides, he produces organic and bio fertilizers with fungicide properties to improve and protect his crops. As a community leader and member of an agro-ecologic network, he is also engaged in the dissemination of these practices amongst farmers of other parishes, either as an instructor or by using his own farm for teaching. He cultivates approximately 0,4 ha between owned and rented land. (Villacis, 2015) His system can be described as intensive. To increase the use of land, he associates different crops with different cycles of production. This allows him to reduce costs, transforming his production from extensive to intensive use of land, an appropriate answer to the specific condition of the fragmented lands in San Joaquin. In his land, he also raises small animals like rabbits and guinea pigs, which he consumes and sells. At the same time, he has worked to reduce his chain of commercialization, which allows him to reach a higher selling prices by avoiding intermediaries. He delivers daily to a big supermarket in the city, and to one restaurant. Other part of his production is sold to consumers who visit his parcel and for whom he harvests on the spot. Only the remaining production is commercialized at Feria Libre, where prices are lower.

\section{Territorial Transformations I. Infrastructure and agriculture}

The decline in the exportations of toquilla hat during the first half of twentieth century, was followed by important migratory movements from the highlands towards the coast of the country, where export-oriented agricultural production had started and needed high quantity of labor workers. (Acosta, Lopez \& Villamar, 2006) Interregional networks built by seasonal work migration to the coast, were partially transformed or complemented with commercial ones ${ }^{16}$, when during the fifties the construction of a national road system finally connected Cuenca to fast-growing cities such as Guayaquil and Machala. Initially used for commercializing traditional products such as flowers, vegetables and basketry in small scale, the new road infrastructure boosted agricultural production to a commercial scale, transforming the productive landscape of San Joaquin. Small and medium landholders progressively turned their chacras ${ }^{17}$ into vegetable crops, while they were building, branching and expanding systems of irrigation into their lands. (Loyola, 2013; Villacis, 2015)

\section{Territorial Transformations II. Infrastructure and urbanization}

At the same time that in San Joaquin commercial agriculture consolidated, Cuenca started a process of modernization and expansion from the fifties onwards. The middle and higher classes progressively took the flat lands of El Ejido at the southern side of Tomebamba river. (Rivera \& Moyano, 2002) In the early seventies, the construction of the north and western part a ring road oriented urbanization towards those areas. First on the cheaper and steeper lands of the northern side, and later towards the flat and productive western lands the valley. New roads were created and existing were expanded towards the new avenue, conforming an irregular grid based mainly on the parcels pattern.

Local farmers have continuously fought urbanizing attempts, mostly put forward by wealthy people, who inherited or purchased lands in the horticultural area, (Loyola, 2013; Villacis, 2015) and for whom these lands do not represent an agricultural asset but an economic investment. In 1995, the Medio Ejido motorway was built, crossing the productive lands of San Joaquin, and bordering the above mentioned properties, in despite of strong opposition from farmers, generally small and medium landowners. The construction was justified in

\section{|!}

${ }^{16}$ Commerce with the coast had been practiced since pre-colonial times, through routes intermittently reactivated during the colony and in a more continuous manner during the heyday of toquilla hats exportation.

${ }^{17}$ Traditional crop of the Andean highlands. The chacra is a system of associated crops consisting mostly of maize, in combination with one or two types of legumes and a type of tuberculum. 
releasing traffic pressure from Ordoñez Lazo Avenue, the main exit of the city towards the coast. A special land regulation (Municipal Council of Cuenca, 2001) was enacted in 2001 in order to prevent San Joaquin from being urbanized. The ordinance stablished low densities of occupation as method to prevent urbanization, but at the same time, it incorporated lands of intense agricultural use inside the urban demarcation of the city. Lands of rural use and urban demarcation are specially hunted by developers. This added to the raising property taxes on urban land, hardens the economic situation of farmers, who often end up selling their properties.

A reform made in 2010 (Municipal Council of Cuenca, 2010) revoked the one of 2001, reducing the minimum size of plots, and laying out a grid of streets that basically follows the pattern of cercos in areas of agricultural production.[fig.7] That is the ordinance currently at work and the one guiding the opening of streets in the agricultural lands. Incongruously, among the listed reasons and motivations to reform the previous ordinance were the recognition of the contribution of agricultural activities to food self-sufficiency of the city and to the parish economy; the necessity of supporting the local initiative for undertaking agroecological practices, and the acknowledgement of the landscape qualities of the sector and the importance of its protection. In some sectors of San Joaquin, a profusion of minor roads and disperse urbanization is the result, partially encouraged by the very ordinance. The areas of medium and big landownerships have consolidated as high income neighborhoods and gated communities are already under construction next to the exclusive tennis and golf club in the farthest western ejidos between the Tomembamba and Yanuncay. At the same time, the last pockets of agriculture remain productive in a highly fragmented land laying behind 'walls' of urbanization along the access roads to San Joaquin.

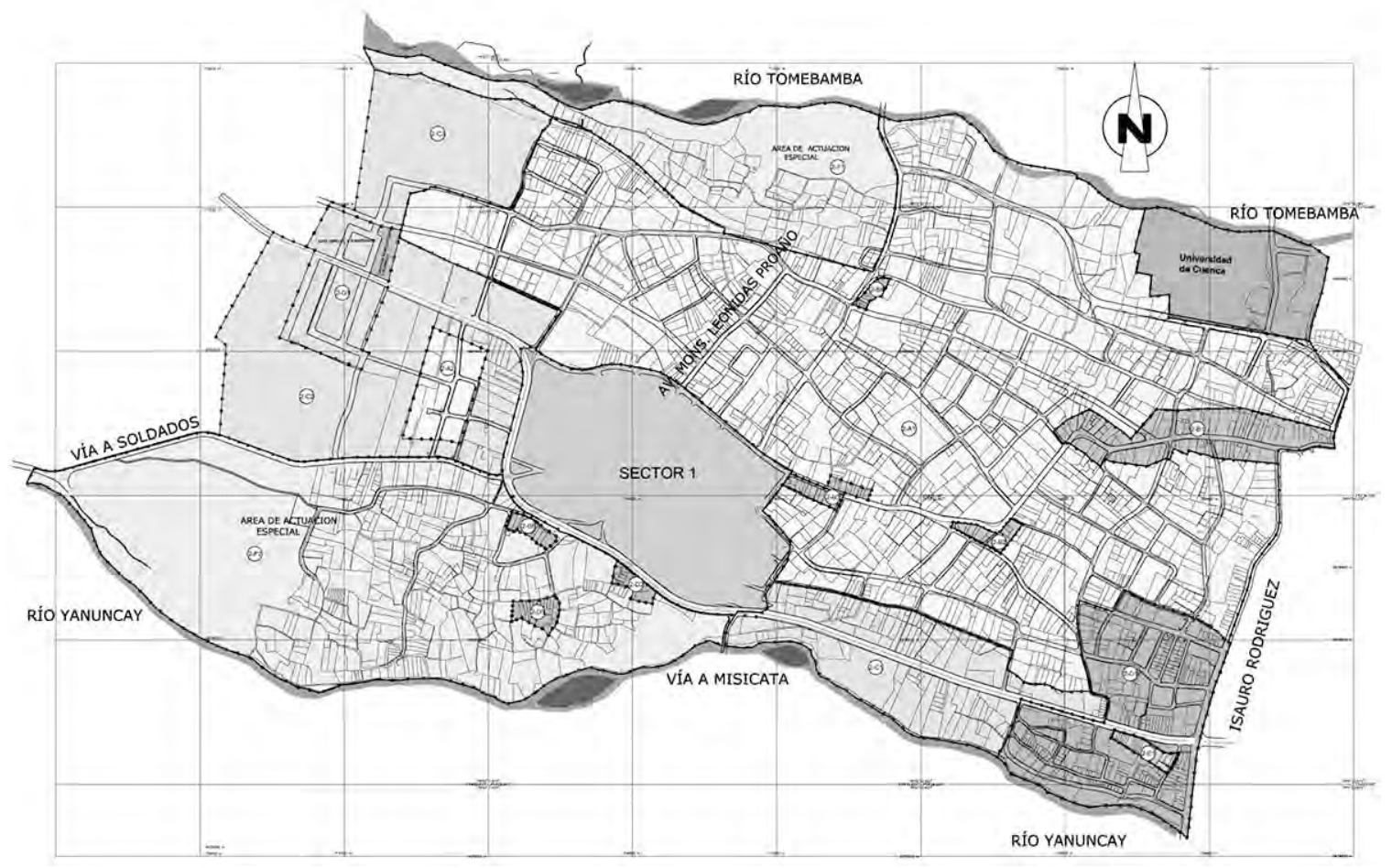

[fig.7] Planning for the Lower area of Balzay (Sector 2). While recognizing the existence and importance of agriculture in the sector, the Plan of Territorial Development of San Joaquin proposes to "frame" the agricultural lands by means of roads. Sector 1 corresponds to the head of the Parish, the most urban consolidated sector. Source: Municipality of Cuenca.

\section{Conclusion: Further transformations and opportunities}

Roads are ideologically very related to the idea of "progress" in the Ecuadorian context, therefore they are the preferred way of politicians to show voters that work has been done. The engineering studies for the construction of a new ring road are ready since 2008 in the Municipality of Cuenca, and the current mayor of Cuenca wants this to be his emblematic project. The proposed layout for the new motorway would transverse both, Tomebamba and Yanuncay rivers at the border of the flat topography in San Joaquin. It is easy to predict, that fast urbanization of the remaining flat lands would follow. 
Despite the increasingly dominant role that road infrastructure has today in the transformation of the landscape of San Joaquin, the structuring elements that make this landscape unique are still present. They can be read as a collective creation, a system composed of natural and cultural elements. Jackson (1986) has powerfully defined landscape not as a natural feature of the environment but as a synthetic space. Landscape is, "a man-made system of spaces superimposed on the face of the land, functioning and evolving not according to natural laws but to serve a community -for the collective character of the landscape is one thing that all generations and all points of view have agreed upon". (Jackson, 1986,8)

Defined in this manner, Landscape stresses the incremental capacity of building networks hosted by inhabited landscapes, which in its turn can be considered as an available resource to be accounted for in envisioning possible futures of our territories. Scattered patterns of occupation can also be sustainable ways of inhabiting the territory, due to qualities of complementarity and a multitude of interplays delivered in the pattern. Under this light, the disperse type of occupation in the surrounding parishes of Cuenca should not be battled, but firstly properly qualified, and the elements of their landscape, which comprises the physical and the cultural, understood as a primary territorial resource.

It is necessary and possible to structure the undergoing processes of urbanization in San Joaquin, allowing for gradual transition and a certain degree of flexibility. This would allow the diverse population that inhabits San Joaquin, especially those whose activities are anchored in the territory and its qualities, to make a transition at their own pace. On the other hand, structuring the territory in relation to its existing elements, would mean to profit from spatial resources that are available and which are embedded in its territorial rationalities.

\section{References}

Achig Subía, L., 2012. La política tributaria en la Gobernación de Cuenca a finales del período colonial: tributación, recaudación, evasión, corrupción e insurrección.

Acosta, A., López, S., Villamar, D., 2006. La migración en el Ecuador: oportunidades y amenazas, 1st ed, Estudios internacionales. Corporación Editora Nacional : Universidad Andina Simón Bolívar, Sede Ecuador, Quito.

Chacón Zhapán, J., 1990. Historia del corregimiento de Cuenca (1557 - 1777). Banco Central del Ecuador.

de Merisalde y Santisteban, Joaquin. 1894. "Relacion Historica, Politica y Moral de la Ciudad de Cuenca, 1765." In

Tres tratados de América (siglo XVIII). Vol. 11. Coleccion e libros raros y curiosos que tratan de America. Madrid: V. Suárez.

Chacón, J., Espinoza, L., Achig, L., Martínez, R., Palomeque, S., Vintimilla, M.A., González, I., Vázquez Méndez, P., Carrasco, A., Cordero, C., 1982. Ensayos sobre historia regional: la región centro sur. Instituto de Investigaciones Sociales de la Universidad de Cuenca.

Habraken, N. J. 1998. The Structure of the Ordinary: Form and Control in the Built Environment. Edited by Jonathan Teicher. Cambridge Mass MIT press.

Jackson, John Brinckerhoff. 1986. Discovering the Vernacular Landscape. New Haven: Yale University Press.

Leon, Luis A., ed. 1983. Compilacion de cronicas, relatos y descripciones de Cuenca y su provincia Tomo III. First. Vol. III. 3 vols. Cuenca: Banco Central del Ecuador.

Loyola, J., 2012. Análisis de la situación Agroecológica y socioeconómica de los productores de San Joaquin. Unpublished de Merisalde y Santiesteban, Joaquín. 1894. "Relación Histórica, Política y Moral de la ciudad de Cuenca, 1765." In Tres tratados de América (siglo XVIII). Vol.11. Colección de libros raros y curiosos que tratan de América. Madrid: V. Suarez.

Municipal Council of Cuenca on Ordenanza que sanciona el Plan de Ordenamiento Territorial de la Parroquia San Joaquin: determinaciones para el uso y ocupación del suelo de las zonas de protección agricola, forestal, ganadera y natural, 2001. (Published on Ecuador's Official Record with Number \#364, July/04/2001), Cuenca.

Municipal Council of Cuenca on Reforma, Actualización, Complementación y Codificación de la Ordenanza que sanciona el Plan de Ordenamiento Territorial de la Parroquia San Joaquin: Determinaciones para el Uso y Ocupación del suelo de la zona de protección agricola, forestal, ganadera y natural, 2010. (Published on Ecuador's Official Record with Number \#99, December/13/2010), Cuenca.

Municipality of Cuenca, Plan de Desarrollo y Ordenamiento Territorial de la Parroquia San Joaquín, (Secretary of Planning, December 2011), Cuenca

Palomeque, S., 1990. Cuenca en el siglo XIX: la articulación de una región. Editorial Abya Yala.

Rivera, M., Moyano, G., 2002. Arquitectura de las Lineas Rectas. Influencia del Movimiento Moderno en la Arquitectura de Cuenca. A Thesis submitted in partial fulfilment of the Requirements of Universidad de Cuenca for the Degree of Architect. Cuenca: Universidad de Cuenca

Simard, J.P., 1997. Formación, desarrollo y configuración socio-étnica de una ciudad colonial: Cuenca, siglos XVIXVIII. Anuario de Estudios Americanos 54, 413-445.

Simard, J.P., 2006. El mosaico indígena: movilidad, estratificación social y mestizaje en el corregimiento de Cuenca (Ecuador) del siglo XVI al XVIII. Editorial Abya Yala. 


\section{Bibliography}

Avila Sánchez, H., 2005. Lo urbano-rural, ¿nuevas expresiones territoriales? Universidad Nacional Autónoma de México, Centro Regional de Investigaciones Multidisciplinarias, Cuernavaca, Morelos.

Bray, T.L., 2008. Late Pre-Hispanic Chiefdoms of Highland Ecuador, in: Silverman, H., Isbell, W.H. (Eds.), The Handbook of South American Archaeology. Springer New

Bhabha, H.K., 2008. The location of culture, 3th reprint. ed. London Routledge.

Bhabha, H., 1997. Culture's In-Between, in: Questions of Cultural Identity. London Sage, pp. 53-60.

Conzen, M.R.G., 1960. Alnwick, Northumberland: A Study in Town-Plan Analysis. Transactions and Papers (Institute of British Geographers) iii-122. doi:10.2307/621094

González, J.G., Bel, J.S., 2009. El valor estructurante del patrimonio en la transformación del territorio. Apuntes: Revista de estudios sobre patrimonio cultural-Journal of Cultural Heritage Studies 22, 20-33.

Habraken, N.J., 1998. The structure of the ordinary: form and control in the built environment. Cambridge Mass MIT press.

Jackson, J.B., 1986. Discovering the Vernacular Landscape. Yale University Press, New Haven.

Kay, C., 2009. Estudios rurales en América Latina en el periodo de globalización neoliberal: una nueva ruralidad? Revista mexicana de sociología 71, 607-645.

Makowski, K., 2008. Andean Urbanism, in: Silverman, H., Isbell, W.H. (Eds.), The Handbook of South American Archaeology. Springer New York, pp. 633-657.

Mora, S., 1878. Plano de la ciudad de Cuenca. Published in: Tratado de Geografía Histórica descriptiva de la República del Ecuador, arreglado para la enseñanza de los niños por los Hermanos de las Escuelas Cristianas de La Salle; Cuenca, pp 236.

Murra, J.V., 1975. Formaciones económicas y políticas del mundo andino. Instituto de Estudios Peruanos, Lima.

Simard, J.P., 2006. El mosaico indígena: movilidad, estratificación social y mestizaje en el corregimiento de Cuenca (Ecuador) del sglo XVIal XVIII. Editorial Abya Yala.

Tapia, M.R., 2014. Prácticas y saber ancestrales de los agricultores de San Joaquin. A thesis submitted in partial fulfilment of the Requirements of Universidad Politecnica Salesiana for the Degree of Master in Andean rainforest Agro ecology. Cuenca: Universidad Politecnica Salesiana.

Viganò, P., 2014. Territorialism. Harvard University Press, Harvard.

Viganò, P., 2012. Elements for a Theory of the City as a renewable resource. A Design and Research Programme, in: Recycling City: Lifecycles, Embodied Energy, Inclusion. Pordenone Giavedoni.

\section{Interviews}

Albarracin, A., 2015. Interview with Avelina Albarracin. Interviewed by Author, 21 February 2015. San Joaquin. [Recording in possession of author]

Avilez, N., 2015. Interview with Narciza Avilez. Interviewed by Author, 29 January 2015. San Joaquin. [Recording in possession of author]

Barros, M., 2015. Interview with Maria Barros. Interviewed by Author, 29 January 2015. San Joaquin. [Recording in possession of author]

Carrillo, D., Carrillo, Z., 2015. Interview with Dora and Zaida Carrillo. Interviewed by Author, 30 January 2015. San Joaquin. [Recording in possession of author]

Chabla, C., 2015. Interview with Catalina Chabla. Interviewed by Author, 29 January 2015. San Joaquin. [Recording in possession of author]

Chumbi, A., 2015. Interview with Ana Micaela Chumbi. Interviewed by Author, 6 February 2015. Flowers Market. [Recording in possession of author]

Duran, M. A., 2015. Interview with Matilde Amparito Duran. Interviewed by Author,28 January 2015. San Joaquin. [Recording in possession of author]

Guaman, R, 2015. Interview with Rosa Guaman. Interviewed by Author, 6 February 2015. Flowers Market. [Recording in possession of author]

Guaman, R., 2015. Interview with Rosario Guaman. Interviewed by Author, 8 August 2015. San Joaquin. [Recording in possession of author]

Guaman, F., 2015. Interview with Fanny Guaman. Interviewed by Author, 5 February 2015. "Feria Libre" wholesalemarket. [Recording in possession of author]

Narvaez, C. 2015. Interview with Carmita Narvaez. Interviewed by Author, 6 February 2015. Flowers Market. [Recording in possession of author]

Narvaez, J., 2015. Interview with Julia Narvaez. Interviewed by Author, 6 February 2015. Flowers Market. [Recording in possession of author]

Pindo, S., 2015. Interview with Silvia Pindo. Interviewed by Author, 29 January 2015. San Joaquin. [Recording in possession of author]

Villacis, L., 2015. Interview with Luis Villacis. Interviewed by Author, 27 January 2015. San Joaquin. [Recording in possession of author]

Wishco, R., 2015. Interview with Rosa Wishco. Interviewed by Author, 27 January 2015. Banos.[Recording in possession of author] 